\title{
Detection of Flavescence Dorée Phytoplasma in Grapevine by Reverse-Transcription PCR
}

P. Margaria, Istituto di Virologia Vegetale, CNR, 10135 Torino, Italy; C. Rosa, University of California, Department of Plant Pathology, Davis 95616; and C. Marzachì, M. Turina, and S. Palmano, Istituto di Virologia Vegetale, CNR, Torino

\begin{abstract}
Margaria, P., Rosa, C., Marzachì, C., Turina, M., and Palmano, S. 2007. Detection of flavescence dorée phytoplasma in grapevine by reverse-transcription PCR. Plant Dis. 91:1496-1501.

Flavescence dorée (FD) is the most serious phytoplasma disease of grapevine. This report describes a novel method of detecting FD phytoplasma based on reverse-transcription polymerase chain reaction (RT-PCR) on 16S ribosomal RNA (16SrRNA) which will greatly improve mass screening of infected grapevines. A rapid protocol for extracting sap from whole leaves or midveins and successive one-tube amplification by RT-PCR was applied to grapevine samples with or without symptoms collected from different areas of Piedmont (northwestern Italy). Results were compared with those obtained using one of the current diagnostic methods that utilizes nested PCR on phytoplasma DNA-enriched preparations. A Cohen's kappa index of 0.76 indicated a substantial agreement between the two sets of results. The RT-PCR method has the advantage of being a rapid, reliable, and sensitive assay for large-scale screening of grapevines.
\end{abstract}

Flavescence dorée (FD) is one of the most serious diseases of grapevine, present in important wine-producing areas such as southern France, northern Italy, and Spain $(3,5,6,9,21)$. To limit further spread, FD is subject to quarantine restrictions in Europe. The disease is associated with a phytoplasma of the $16 \mathrm{Sr}-\mathrm{V}$ group, recently proposed as 'Candidatus Phytoplasma vitis' (25). Its only natural vector is the leafhopper Scaphoideus titanus Ball (Homoptera: Cicadellidae) (12).

FD control strategies are based on preventive measures such as insecticide treatments against the vector and rouging of the diseased vines. Nevertheless, the economic loss is important and the disease continues to spread. Early and reliable detection is necessary to eliminate infected plants, and to distinguish FD from other phytoplasmas that also cause yellows diseases in grapevines (9) but are not subjected to mandatory control measures, such as Bois noir (BN, $16 \mathrm{Sr}-\mathrm{XII}$ group) (27) that is endemic throughout most all European viticulture (9). Therefore, effort has been focused on developing more rapid, versatile, and efficient diagnostic methods $(10,13,34)$.

Phytoplasma diagnosis in grapevines is hampered by the low phytoplasma titer and uneven spatial distribution in the plant, together with variations in titer according

Corresponding author: Sabrina Palmano

E-mail: s.palmano@ivv.cnr.it

Accepted for publication 28 June 2007.

doi:10.1094/PDIS-91-11-1496

(C) 2007 The American Phytopathological Society to season $(7,15,40)$. Moreover, plant phenolics and polysaccharides can inhibit Taq polymerase activity in the polymerase chain reaction (PCR) $(10,18)$. Many extraction procedures have been developed to increase phytoplasma DNA concentration in the final extract $(10,34)$. Routinely, the pathogen is detected by PCR amplification using the conserved 16S rRNA gene as target $(1,19)$. To increase sensitivity, a nested PCR with specific primers $(10,13,17,24,29)$ is necessary for FD diagnosis on grapevine samples; however, the nested step increases the risk of contamination and false positives. To avoid this, other strategies have been developed, such as hybridization of the first amplicon with a specific oligonucleotide probe (20), PCR enzyme-linked immunosorbent assay (35), DNA microarray technique (8), and realtime PCR (23). DNA-based methods rely on a relatively pure DNA template whose extraction is expensive and time consuming, making the overall detection protocols unsuitable for large-scale use. Using antibodies for diagnostics $(11,26)$ is inexpensive and fast but, at present, is not sensitive enough to detect most FD infections in grapevine samples. Therefore, a more efficient and rapid method for FD phytoplasma diagnosis is needed.

We introduce a simple, quick, sensitive, and reliable method for mass screening of FD in grapevine based on reversetranscription (RT)-PCR amplification of the 16S rRNA of FD phytoplasma. The procedure was compared with the diagnostic method routinely used in our laboratory (30) that was considered the most sensitive in a comparison carried out in different Italian laboratories (4).
MATERIALS AND METHODS

Sample collection and symptom analysis. In all, 232 grapevines were tested in parallel. Samples were collected during 2005 from June to October in vineyards and nurseries in several southeastern areas of Piedmont, stored at $4^{\circ} \mathrm{C}$, and processed within 2 days. Samples were scored for the presence of 10 different symptoms designated as S1: absence of flowering; S2: short internodes, small and rolled leaves late in the season; S3: reddening or yellowing around the veins; S4: withering of the inflorescence and grape berries; S5: reddening or yellowing of leaf tissues between the main veins; S6: early leaf fall with or without the petiole; S7: grape berries withering after bunch closure; S8: lacking or irregular shoot lignification; S9: triangular leaves from late spring exhibiting leaf rolling; and S10: leaf thickening and brittle consistency. Symptom scoring was used only on field grapevines (163 samples) and not nursery cuttings (69 samples), where FD symptomatology was not well determined. The co-presence of at least three of the individual symptoms has been considered a good indication of phytoplasma infection in previous literature (31).

Grapevines of the following cultivars were tested: Arneis, Barbera, Blanche de Morgeaux, Bonarda, Brachet, Chardonnay, Cortese, Croatina, Dolcetto, Erbaluce, Favorita, Freisa, Grignolino, Isabella, Merlot, Moscato, Nebbiolo, Neretto, Pinot Noir, Petit Rouge, Syrah, Ruchè, Vermentino, and Vespolina.

Leaf sap extraction and RT-PCR analysis for detecting FD phytoplasma $16 S$ rRNA. Samples consisting of $0.2 \mathrm{~g}$ of leaf tissue or midvein tissue were placed in extraction bags (Bioreba, Reinach, Switzerland) and homogenized in grape grinding buffer $\left(15 \mathrm{mM} \mathrm{Na}_{2} \mathrm{CO}_{3}, 34.9 \mathrm{mM} \mathrm{Na}-\right.$ $\mathrm{HCO}_{3}, 2 \%$ polyvinyl-pyrrolidone [PVP]$40,0.2 \%$ bovine serum albumin [BSA], $0.05 \%$ Tween 20 , and $1 \% \mathrm{Na}_{2} \mathrm{~S}_{2} \mathrm{O}_{5}, \mathrm{pH}$ 9.6) at a final dilution of 1:20 using a Rexon drill press RDM-50A (Taiwan; $33,35)$. The crude extract $(2 \mu \mathrm{l})$ was added to $25 \mu \mathrm{l}$ of sterile buffer $(0.1 \mathrm{M}$ glycine$\mathrm{NaOH}$, pH 9.0, $50 \mathrm{mM} \mathrm{NaCl}, 1 \mathrm{mM}$ EDTA, and $0.5 \%$ Triton X-100), denatured for $10 \mathrm{~min}$ at $95^{\circ} \mathrm{C}$, then placed on ice for 5 min.

Denatured extract $(2 \mu \mathrm{l})$ was added to a final reaction volume of $25 \mu$ l consisting of 
$1 \times$ PCR buffer (Applied Biosystems, Foster City, CA), $3 \mathrm{mM} \mathrm{MgCl}_{2}, 5 \mathrm{mM}$ DTT, $500 \mathrm{nM}$ forward primer, $500 \mathrm{nM}$ reverse primer, $200 \mu \mathrm{M}$ each dNTP, 4 units of RNaseOUT (Invitrogen Life Technologies, Carlsbad, CA), 1 unit of Thermoscript (Invitrogen), and 1.25 units of AmpliTaq Polymerase (Applied Biosystems). The amplification consisted of $30 \mathrm{~min}$ of reverse transcription at $52^{\circ} \mathrm{C}$; followed by 35 cycles at $94^{\circ} \mathrm{C}$ for $30 \mathrm{~s}, 52^{\circ} \mathrm{C}$ for $30 \mathrm{~s}$, and $72^{\circ} \mathrm{C}$ for $20 \mathrm{~s}$; and final extension at $72^{\circ} \mathrm{C}$ for $10 \mathrm{~min}$. The amplified fragments were analyzed in a $2 \%$ agarose gel in Trisborate-EDTA buffer $(45 \mathrm{mM}$ Tris-borate and 1 mM EDTA, pH 8.0).

Primers were designed by aligning with Clustal Software (41) the transcribed region of the $16 \mathrm{~S}$ rRNA from at least one phytoplasma for each of the 15 groups available in various sequence databases searched with BLAST (2). The primers selected for FD amplification were FD221F (5'-TTTAAAAGACCTTCTTCGGA$\left.3^{\prime}\right)$ and FD-483R (5'-ACGTCAAGATAG TTTTTCCACT-3') (Fig. 1).

The specificity of the selected primers was verified by RT-PCR at different annealing temperatures, using as template total leaf extracts from periwinkle plants (Catharanthus roseus) from our collection infected with phytoplasmas of different ribosomal groups (28), including American aster yellows (16Sr-I), Chrysanthemum yellows (16Sr-I) (16), European aster yellows (16Sr-I), tomato big bud (16Sr-I), faba bean phyllody (16Sr-II), Vaccinium witches'-broom (16Sr-III), elm yellows (16Sr-V), FD (16Sr-V), clover proliferation $(16 \mathrm{Sr}-\mathrm{VI})$, apple proliferation $(16 \mathrm{Sr}-$ $\mathrm{X})$, and stolbur (16Sr-XII). The reference isolates were graft propagated and maintained in periwinkle from the original sources kindly supplied by M. F. Clark (Horticulture Research International, East Malling, UK) for American aster yellows, European aster yellows, tomato big bud, faba bean phyllody, clover proliferation, and stolbur. E. Seemüller (Biologische Bundesanstalt, Dossenheim, Germany) supplied Vaccinium witches'-broom, elm yellows, and apple proliferation, and E. Boudon-Padieu (Laboratoire de Phytoparasitologie, INRA, Dijon, France) supplied FD.

To check for repeatability, leaf extracts of some grapevine samples were stored at -20 or $-80^{\circ} \mathrm{C}$ and amplified by RT-PCR after 1 week and then after 4 months. The effect of long-term storage at -20 or $-80^{\circ} \mathrm{C}$ also was evaluated on frozen leaf extracts of FD-infected periwinkles stored for 2 weeks, 1 month, and 5 months at these temperatures. At the same time, whole leaves from some grapevine samples were stored at $4^{\circ} \mathrm{C}$ and total tissue extracts then were used for amplification by RT-PCR 1 week after collection.

Given that the crude extracts contained DNA as well as RNA, we wished to test for possible amplification of FD phytoplasma DNA during the RT-PCR reaction. For this purpose, six RT-PCR-positive grapevine samples were used for direct RT-PCR amplification without adding reverse transcriptase to the reaction mixture. Negative controls in the RT-PCR assays consisted of whole-leaf extracts from symptomless grapevines collected from fields where no type of grapevine yellows was yet present, and from periwinkles grown from seed in insect-proof greenhouses.

Nested-PCR for detecting FD phytoplasma DNA. Midveins from the same samples processed in RT-PCR were used in parallel experiments for enriched DNA extraction and nested PCR. DNA was extracted using an enrichment protocol for phytoplasmas $(1,34)$. Two consecutive PCR amplifications were conducted. The first reaction utilized the universal phytoplasma primers (P1 and $\mathrm{P} 7$ ) designed on the 16S rRNA and 23S rRNA genes, respectively $(19,39)$, followed by a nested PCR using $16 \mathrm{Sr}-\mathrm{V}$ group-specific primers (29). The PCR template was prepared from $1.5 \mathrm{~g}$ of midveins from fresh leaves, ground in $15 \mathrm{ml}$ of phytoplasma grinding buffer $\left(100 \mathrm{mM} \quad \mathrm{K}_{2} \mathrm{HPO} 4,30 \mathrm{mM}\right.$ $\mathrm{KH}_{2} \mathrm{PO}_{4}, 10 \%$ sucrose, $0.15 \%$ BSA fraction $\mathrm{V}, 2 \%$ PVP-10, and $25 \mathrm{mM}$ ascorbic acid, $\mathrm{pH}$ 7.6) in an ice-cold mortar. The homogenate was centrifuged for $5 \mathrm{~min}$ at $2,500 \times g$ and the supernatant then was transferred to chilled tubes and centrifuged for $20 \mathrm{~min}$ at $18,000 \times \mathrm{g}$. The pellet was resuspended in $1 \mathrm{ml}$ of cetyltrimethylammonium bromide (CTAB) buffer (2\% CTAB, $100 \mathrm{mM}$ Tris, pH 8.0, $1.4 \mathrm{M} \mathrm{NaCl}$, $20 \mathrm{mM}$ EDTA) and incubated at $60^{\circ} \mathrm{C}$ for at least $20 \mathrm{~min}$. Nucleic acids were purified by chloroform followed by two precipitations, one in isopropanol and the second in ethanol. The final DNA pellet was resuspended in $100 \mu \mathrm{l}$ of sterile water and $2 \mu \mathrm{l}$ were used as PCR template. Total DNA from healthy grapevines grown from seed was used as a negative PCR control. The nested-PCR assay also was used to detect $\mathrm{BN}$ in all the grapevine samples (29).

Comparison of nested PCR with RTPCR and statistical analysis. The level of agreement between RT-PCR results and the corresponding nested-PCR assay was estimated using the Cohen's kappa coefficient. A kappa index of $0,0.0$ to $0.2,0.21$ to $0.4,0.41$ to $0.60,0.61$ to 0.80 , and 0.81 to 1.00 indicates poor, slight, fair, moderate, substantial, and almost perfect agreement, respectively (14).

Diagnostic sensitivity, specificity, and efficiency of RT-PCR versus nested-PCR results were calculated as previously reported (22), unifying the RT-PCR results from leaves and from midveins. It was assumed that the correlation between the two techniques was good when parameter values were greater than $90 \%$ (37).

\section{RESULTS}

Symptom analysis. Symptoms associated with each sample varied greatly, including samples with few or no specific symptoms, or exhibiting all of the typical symptoms described for phytoplasma infection. Samples that did not show phytoplasma-specific symptoms always tested negative for FD and BN. Thirty-three samples showing at least three phytoplasmalike symptoms were negative for FD with both methods but were found to be $\mathrm{BN}$ positive by nested PCR, confirming a good correlation between symptoms and phytoplasma infection. Fifteen field samples were positive for both FD and BN and the symptoms on these plants were not significantly different.

RT-PCR and nested-PCR results. The specificity of the primers designed for RTPCR was evaluated on periwinkles infected with phytoplasmas of different groups (Fig. 1). Using an annealing temperature of $52^{\circ} \mathrm{C}$, we obtained positive results only from group $16 \mathrm{Sr}$-V-infected periwinkles (Fig. 2). From a total of 232 samples, 135 were found to be FD-positive and 97 FD-negative by nested PCR, whereas 122 samples tested positive and 110 tested negative for FD by RT-PCR. Of the 135 samples that tested FD-positive with nested PCR, 115 (85.2\%) also were positive by RT-PCR and, of the 97 samples that were FD-negative by nested PCR, 90 $(92.8 \%)$ were also negative by RT-PCR.

Seven samples, five of which were scored for phytoplasma-specific symptoms, were FD-positive with RT-PCR but negative with nested PCR (Table 1). The same samples tested for BN phytoplasma by nested PCR were negative, indicating a good correlation between symptoms and RT-PCR results. Twenty samples were positive by nested PCR but negative with RT-PCR (Table 1). Fourteen of these samples were field grapevines and were scored for specific symptoms. Only eight samples showed three or more of these symptoms. This suggests that some of the 20 nestedPCR-positive samples may have been false positives.

Extracts of 123 samples were obtained separately from midveins and whole leaves and were compared by RT-PCR in parallel assays. The results obtained from midveins and whole leaves of each respective sample were identical ( 73 positive, 50 negative), except for two samples that were positive only from whole leaves, which was consistent with nested-PCR results These two samples were considered positive in the statistical analysis performed to compare RT-PCR results with nested-PCR results. In all cases, we obtained stronger signals from whole leaves than from midveins (data not shown).

Amplification from total extracts of grapevine tissue in grapevine grinding buffer stored at -20 or $-80^{\circ} \mathrm{C}$ was repeated after different periods of storage. When 
leaf extracts of six samples that tested positive for FD by RT-PCR were retested after 1 week at $-80^{\circ} \mathrm{C}$, and when another batch of six positive samples were retested after 1 week at $-20^{\circ} \mathrm{C}$, the results of all tests were positive for FD. Two samples were refrozen and stored for an additional
4 months at $-80^{\circ} \mathrm{C}$ and again tested positive after this period.

We also used total whole leaf extracts from FD-infected periwinkles maintained in the greenhouse. Extracts from 10 different such periwinkles were tested by RTPCR, frozen at $-20^{\circ} \mathrm{C}$, and tested again after 2 weeks, 1 month, and 5 months. Each extract consistently tested positive, as did the fresh extracts (data not shown). Positive RT-PCR results also were obtained from infected grapevine leaf samples held 1 week in the cold room after collection.

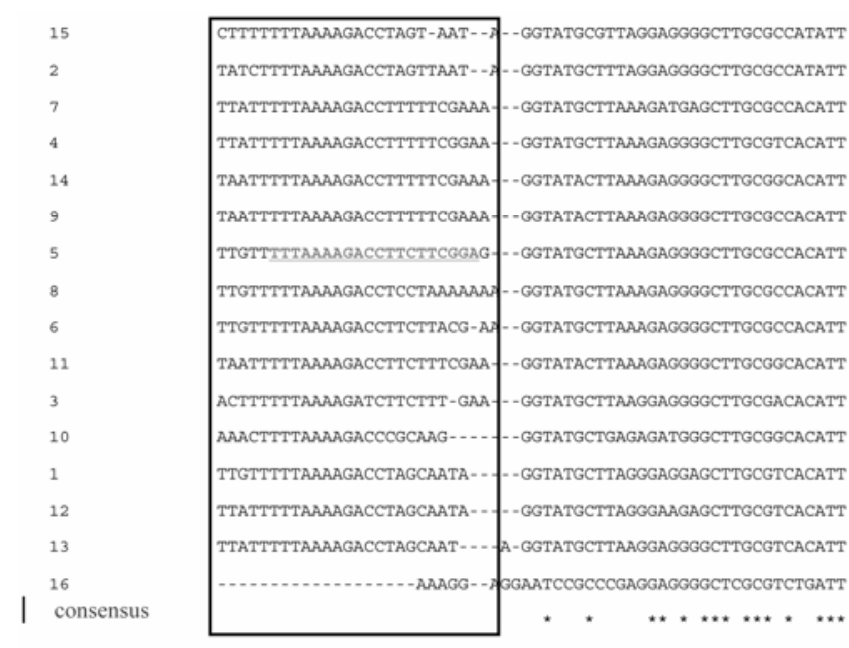

15

2

7

10 AGTTAGTTGGTAGGGTAAAGGCCTACCAAGACGATGATGTGTAGCTGGACTGAGAGGTTG
13

16

| consensus

15

2

7

4

14

9

5

8

11

3

10

12

13

16

| consensus
AGTTAGTTGGTAAGGTAACGGCTTACCAAGACGATGATGTGTAGCTGGACTGAGAGGTTG AGTTAGTTGGTAGGGTAATGGCCTACCAAGACGATGATGTGTAGCTGGACTGAGAGGTTG AGTTTGTTGGTGGGGTAATGGCCTACCAAGACGATGATGTGTAGCTGGACTGAGAGGTCG AGTTAGTTGGTAGGGTAAAAGCCTACCAAGACTATGATGTGTAGCTGGACTGAGAGGTTG AGTTAGTTGGTAAGGTAAAAGCTTACCAAGACGATGATGTGTAGCTGGACTGAGAGGTCG AGTTAGTTGGTGAGGTAAAGGCTTACCAAGATTATGATGTGTAGCTGGACTGAGAGGTTG AGTTTGTTGGTAAGGTAATGGCTTACCAAGACTATGATGTGTAGCTGGACTGAGAGGTTG AGTTAGTTGGTAGAGTAAAAGCCTACCAAGACGATGATGTGTAGCTGGACTGAGAGGTTG AGTTAGTTGGTAGGGTAATGGCCTACCAAGACTATGATGTGTAGCTGGACTGAGAGGTTG AGTTAGTTGGTAGGGTAAAGGCCTACCAAGACTATGATGTGTAGCTGGACTGAGAGGTTG AGTTAGTTGGTAAGGTAACGGCTTACCAAGACCATGATGTGTAGCTGGACTGAGAGGTTG AGTTAGTTGGTGGGGTAAAGGCCTACCAAGACTATGATGTGTAGCCGGGCTGAGAGGTTG AGTTAGTTGGTGGGGTAATGGCCTACCAAGACGGTGATGTGTAGCCGGGCTGAGAGGTCG AGTTAGTTGGTAGGGTAAAAGCCTACCAAGACAATGATGTGTAGCCGGGCTGAGAGGTTG AGCTAGTTGGTGAGGCAATAGCTTACCAAGGCGATGATCAGTAGCTGGTCCGAGAGGATG

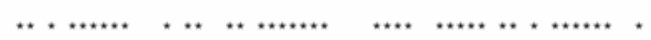

AACAGCCACATTGGGACTGAGACACGGCCCAAACTCCTACGGGAGGCAGCAGTAAGGAAT AACAGCCACATTGGGACTGAGACACGGCCCAAACTCCTACGGGAGGCAGCAGTAGGGAAT AACAGCCACATTGGGACTGAGACACGGCCCAAACTCCTACGGGAGGCAGCAGTAGGGAAT AACAGCCACATTGGGACTGAGACACGGCCCAAACTCCTACGGGAGGCAGCAGTAGGGAAT AACAGCCACATTGGGACTGAGACACGGCCCAAACTCCTACGGGAGGCAGCAGTAGGGAAT AACAGCCACATTGGGACTGAGACACGGCCCAAACTCCTACGGGAGGCAGCAGTAAGGAAT AACAGCCACATTGGGACTGAGACACGGCCCAAACTCCTACGGGAGGCAGCAGTAGGGAAT AACAGCCACATTGGGACTGAGACACGGCCCAAACTCCTACGGGAGGCAGCAGTAGGGAAT AACAGCCACATTGGGACTGAGACACGGCCCAAACTCCTACGGGAGGCAGCAGTAGGGAAT AACAGCCACATTGGGACTGAGACACGGCCCAAACTCCTACGGGAGGCAGCAGTAGGGAAT AACGGCCACATTGGGACTGAGATACGGCCCAAACTCCTACGGGAGGCAGCAGTAAGGAAT AACGGCCACATTGGGACTGAGACACGGCCCAAACTCCTACGGGAGGCAGCAGTAGGGAAT AACGGCCACATTGGGGCTGAGACACGGCCCAAACTCCTACGGGAGGCAGCAGTAAGGAAT AACGGCCACATTGGAACTGAGACACGGTCCAAACTCCTACGGGAGGCAGCAGTAGGGAAT ATCAGCCACACTGGGACTGAGACACGGCCCAGACTCCTACGGGAGGCAGCAGTGGGGAAT

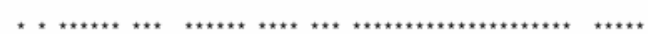
AACAGCCACATTGGGACTGAGACACGGCCCAAACTCCTACGGGAGGCAGCAGTAGGGAAT

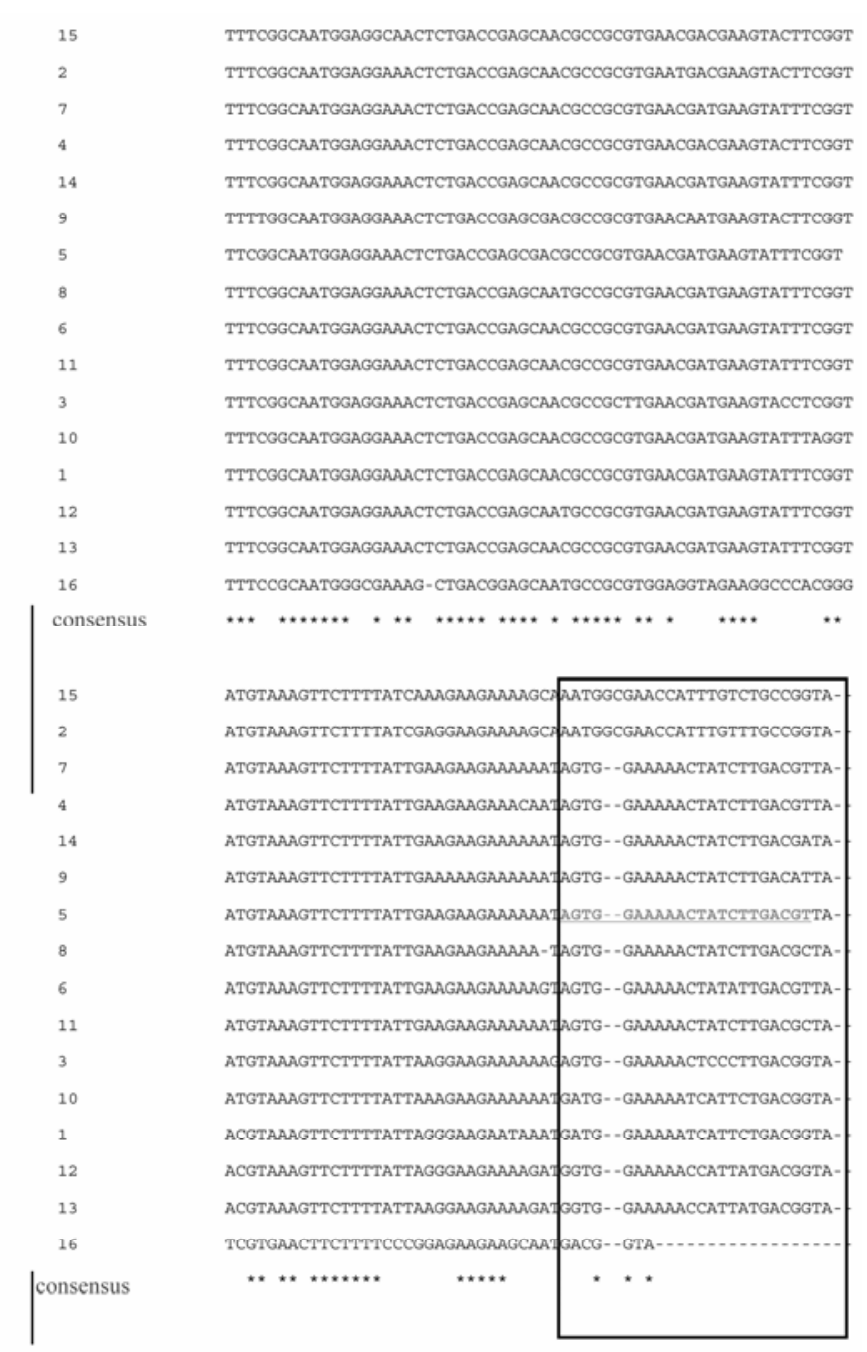

Fig. 1. Alignment (Clustal X-1.81) of $16 \mathrm{~S}$ ribosomal nucleotide sequences from Vitis vinifera and several phytoplasma sequences available in GenBank (listed below). Primers designed for Flavescence dorée (FD) phytoplasma amplification are in bold and underlined. 1, Onion yellows (16Sr-I) (AP006628); 2, peanut witches'-broom (16Sr-II) (L33765); 3, Western X (16Sr-III) (L04682); 4, coconut lethal yellows (16Sr-IV) (AF498309); 5, FD (16Sr-V) (AF176319); 6, clover proliferation (16Sr-VI) (L33761); 7, ash yellows (16Sr-VII) (AF189215); 8, loofah witches'-broom (16Sr-VIII) (L33784); 9, pigeon pea witches'-broom (16Sr-IX) (AY248753); 10, pear decline (16Sr-X) (Y16392); 11, rice yellow dwarf (16Sr-XI) (D12581); 12, stolbur (16Sr-XII) (AY739654); 13, Mexican periwinkle virescence (16Sr-XIII) (AF248960); 14, Bermuda grass white leaf (16Sr-XIV) (AJ550984); 15, hibiscus witches'broom (16Sr-XV) (AF127708); and 16, V. vinifera (AJ639615).

1498 Plant Disease / Vol. 91 No. 11 
In order to evaluate whether the DNA also served as template for amplification of the specific FD amplicon obtained by RTPCR, whole-leaf extracts from six grapevine samples that tested FD-positive by RT-PCR were analyzed with the same amplification mixture used in the RT-PCR reaction but omitting reverse transcriptase. Two of the six samples tested positive for FD.

Comparison of nested PCR with RTPCR and statistical analysis. To calculate the diagnostic parameters for comparison of the nested-PCR and RT-PCR methods, we arbitrarily considered the results obtained by nested-PCR as reference standards (i.e., true positive and true negative), whereas false positives and false negatives were considered to be those RT-PCR results which did not correspond with the nested-PCR results. The values calculated for the various diagnostic parameters are shown in Table 2. Comparing results from RT-PCR and nested PCR, we obtained a Cohen's kappa index of 0.76, suggesting a substantial agreement between the results of the two methods. Confidence interval ( $\alpha$ $=0.05$ ) for kappa was $0.76 \pm 0.083$.

\section{DISCUSSION}

Diagnosis of FD phytoplasma in grapevine is routinely performed by PCR amplification of phytoplasma DNA, but the low pathogen titer in the plant can limit detection. Nested PCR is necessary to enhance sensitivity but also introduces high risks of contamination, increasing the possibility of false-positive results. Moreover, the DNA extraction protocol routinely used is time consuming and involves several steps, increasing the risk of operator error. The method proposed here includes a simple total tissue extraction followed by a onetube RT-PCR reaction $(33,36)$. Reverse transcription can take advantage of the high ribosomal RNA copy number in the pathogen cell, resulting in an increased amount of initial template for amplification even though only two copies of the 16SrRNA gene are present in the phytoplasma genome (38) and available for the nested-PCR approach. Moreover, a positive RT-PCR result implies active metabolism of the pathogen, whereas the nestedPCR approach relies on the mere presence of phytoplasma DNA in the samples, which could be derived from bacteria no longer active. In addition, extraction of the sample without any precipitation step reduces the risk of losing the DNA pellet and avoids co-precipitating inhibitory plant compounds such as phenolics and polysaccharides which consequently are more diluted in the total tissue extract. Avoidance of toxic agents such as phenol and

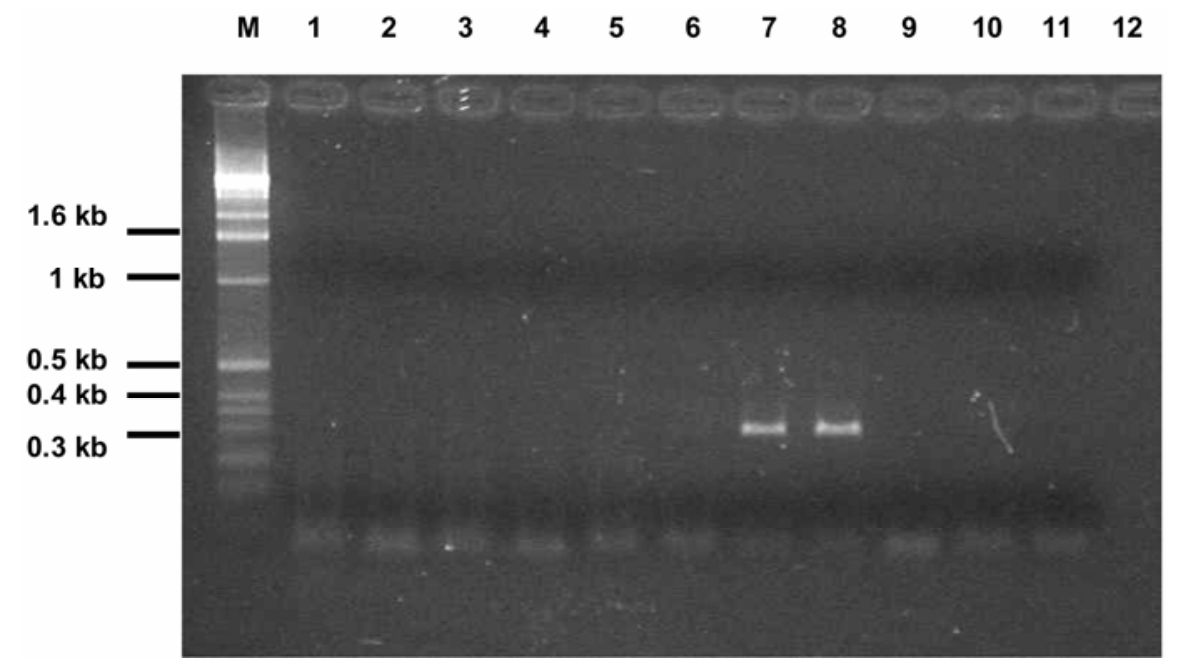

Fig. 2. Reverse-transcription polymerase chain reaction (RT-PCR) of different extracts of periwinkle infected with phytoplasmas belonging to several groups. Primers used were Flavescence dorée (FD)$221 \mathrm{f}$ and $\mathrm{FD}-483 \mathrm{r}$ at an annealing temperature of $52^{\circ} \mathrm{C}$. Lane M, DNA marker (1-kb DNA ladder,); lane 1, American aster yellows (16Sr-I); lane 2, chrysanthemum yellows (16Sr-I); lane 3, European aster yellows (16Sr-I); lane 4, tomato big bud (16Sr-I); lane 5, faba bean phyllody (16Sr-II); lane 6, Vaccinium witches'-broom (16Sr-III); lane 7, FD (16Sr-V); lane 8, elm yellows (16Sr-V); lane 9, clover proliferation (16Sr-VI); lane 10, apple proliferation (16Sr-X); lane 11, stolbur (16Sr-XII); and lane 12 , healthy periwinkle.

chloroform improves safety conditions of the operator and limits the cost of handling and disposal. Furthermore, a single experienced lab technician can process 30 to 40 samples in 3 to $4 \mathrm{~h}$ whereas, with the nested-PCR protocol used for comparison in this study, only 10 samples over 2 days could be processed.

Phytoplasmas are not always detectable in all parts of a grapevine showing symptoms (7). Sampling procedures for tissue to be used in the extraction step is critical, in particular for the RT-PCR method which uses a much smaller initial sample size than that used in nested PCR. This could explain the contradictory results that we obtained in two cases from leaves and midveins of the same grapevine. We recommend that representative samples of leaf tissue be taken from many areas of the plant. Cohen's kappa statistical analysis showed that there was substantial agreement between the RT-PCR and nestedPCR results, even though the RT-PCR failed to detect a number of samples that were positive by nested PCR. A real-time version of the RT-PCR, which we are currently developing, or the introduction of a nested step in the RT-PCR, will improve sensitivity while maintaining the advantage of the rapid and simple whole-tissue template preparation. The statistical parameters selected to compare the RT-PCR with the nested-PCR diagnostic results (Table 2) indicated a satisfactory level of agreement, although the correlation values were sometimes lower than $90 \%$. As a baseline for calculating the parameters, we assumed as valid the results obtained by nested PCR; however, as already noted, this method is subject to error, and no specific biological confirmation of the disease can be provided.

The 20 samples out of 135 that were negative by RT-PCR but positive by nested PCR could be explained in two ways. Either contaminations (false positives) occurred in the nested-PCR method or, more likely, the RT-PCR was a less sensitive detection method. The seven samples that were positive by RT-PCR but negative by nested PCR may have been a result of loss of the DNA pellet during extraction in the conventional approach or presence of inhibitors in the extracted DNA because no endogenous control for amplification of plant DNA was performed. In fact, five field grapevines of these seven samples that were negative for $\mathrm{FD}$ and $\mathrm{BN}$ by nested PCR showed at least three phyto-

Table 1. Phytoplasma-specific symptoms in samples that were positive by reverse-transcription polymerase chain reaction (RT-PCR) but negative by nested PCR for Flavescence dorée phytoplasma (FD) (row 1), and samples that were negative by RT-PCR but positive by nested PCR for FD (row 2) ${ }^{\mathrm{a}}$

\begin{tabular}{|c|c|c|c|c|c|}
\hline \multirow{2}{*}{$\frac{\text { RT-PCR }}{\text { FD pos (7) }}$} & \multicolumn{3}{|c|}{ Samples with a least three phytoplasma-specific symptoms } & \multicolumn{2}{|c|}{ Nested PCR } \\
\hline & Yes (5) & No $(0)$ & NA (2) & FD neg (7) & BN neg (7) \\
\hline FD neg (20) & Yes (8) & No (6) & NA (6) & FD pos $(20)$ & $B N \operatorname{pos}\left(4^{b}\right)$ \\
\hline
\end{tabular}

${ }^{a}$ The samples also were tested by nested-PCR for the presence of Bois noir phytoplasma (BN). Numbers in parentheses = number of samples, pos $=$ positive, neg = negative, and NA = not available (nursery cuttings).

${ }^{b}$ Four BN positive samples of the eight showing at least three specific symptoms. 
Table 2. Parameters used for comparing reverse-transcription polymerase chain reaction (RT-PCR) with nested PCR (22), and values obtained

\begin{tabular}{llc}
\hline Parameter & \multicolumn{1}{c}{ Formula $^{\mathbf{a}}$} & Percentage \\
\hline Sensitivity & $(\mathrm{TP} / \mathrm{TP}+\mathrm{FN}) \times 100$ & 87.1 \\
Specificity & $(\mathrm{TN} / \mathrm{TN}+\mathrm{FP}) \times 100$ & 93.3 \\
Efficiency & $(\mathrm{TP}+\mathrm{TN}) /(\mathrm{TP}+\mathrm{FP}+\mathrm{TN}+\mathrm{FN}) \times 100$ & 89.6 \\
\hline
\end{tabular}

${ }^{\text {a }} \mathrm{TP}=$ true positives, defined as number of samples positive in nested-PCR; FN = false negatives, defined as number of samples negative only with RT-PCR; TN = true negatives, defined as number of samples negative with nested-PCR; and FP = false positives, defined as number of samples positive only in RT-PCR.

plasma-specific symptoms (Table 1), lending weight to the positive results in RTPCR.

The almost complete agreement between RT-PCR results obtained from midribs and whole leaves (121 out of 123 samples) and the stronger reactions obtained from leaves demonstrates that isolation of midveins is not necessary for sample preparation, further simplifying the extraction. Amplification also was possible from leaf samples stored for 1 week at $4^{\circ} \mathrm{C}$. This indicates that rRNA is stable enough to allow shipping to the laboratory involving some time and distance.

Phytoplasma DNA served as a template in PCR amplification in the absence of reverse transcriptase in two of six samples tested. This demonstrated that FD phytoplasma DNA was indeed present in the extract, although its function as a template in the amplification reaction was minor. A DNase step could be included if more specific studies with only the RNA template were needed.

Experiments on long-term storage of grapevine and periwinkle leaf extracts in grape-grinding buffer at -20 and $-80^{\circ} \mathrm{C}$ showed that rRNA is stable at these temperatures. This permits reexamination of the negative samples with a nested RTPCR step or with other primer combinations to detect different phytoplasma or viral infections. However, our storage experiments carried out on infected periwinkle samples may have overestimated the template stability, because the phytoplasma titer in periwinkle is much higher than in grapevine (7).

The rapidity, sensitivity, and reliability of the RT-PCR method described here suggest its potential use to detect other diseases of grapevine. Field symptoms similar to those of FD may be induced by other phytoplasmas, such as $\mathrm{BN}$, or by phloem-based viruses. The single-stranded RNA of grapevine viruses and ribosomal RNA of phytoplasmas can be detected from the same whole-leaf extract, overcoming a limitation of DNA-based diagnosis. The RT-PCR method used here for detection of FD is already used for grapevine viruses $(32,33)$. We currently are adapting the same protocol for the detection of $\mathrm{BN}$.

In conclusion, we recommend that RTPCR be used for large-scale screening of field infections. However, the possible existence of a low level of false negatives would suggest caution in its use for phytosanitary assessment of nursery material.

\section{ACKNOWLEDGMENTS}

This work was financed through a grant from Regione Piemonte, "Servizio Fitosanitario Regionale." We thank C. Perrone, F. Veratti, and M. D'Aquilio for excellent technical assistance and R. G. Milne for editing the manuscript.

\section{LITERATURE CITED}

1. Ahrens, U., and Seemüller, E. 1992. Detection of DNA of plant pathogenic mycoplasma-like organisms by a polymerase chain reaction that amplifies a sequence of the 16S rRNA gene. Phytopathology 82:828-832.

2. Altschul, S. F., Gish, W., Miller, W., Myers, E. W., and Lipman, D. J. 1990. Basic local alignment search tool. J. Mol. Biol. 215:403410.

3. Angelini, E., Clair, D., Borgo, M., Bertaccini, A., and Boudon-Padieu, E. 2001. Flavescence dorée in France and Italy: occurrence of closely related phytoplasma isolates and their near relationships to Palatinate Grapevine Yellows and Alder Yellows Phytoplasmas. Vitis 40:79-86.

4. Barba, M., Boccardo, G., Carraro, L., Del Serrone, P., Ermacora, P., Firrao, G., Giunchedi, L., Loi, N., Malfitano, M., Marcone, C., Marzachi', C., Musetti, R., Osler, R., Palmano, S., Poggi Pollini, C., and Ragozzino, A. 1998. Confronto fra differenti tecniche di diagnosi applicate al rilevamento di fitoplasmi in pomacee. Notiziario sulla Protezione delle Piante 9:263-277.

5. Battle, A., Laviňa, A., Kuszala, C., Clair, D., Larrue, J., and Boudon-Padieu, E. 1997. Detection of Flavescence dorée phytoplasma in grapevine in northern Spain. Vitis 36:211-221.

6. Battle, A., Martínez, M. A., and Laviña, A. 2000. Occurrence, distribution and epidemiology of Grapevine yellows in Spain. Eur. J. Plant Pathol. 106:811-816.

7. Berges, R., Rott, M., and Seemüller, E. 2000. Range of phytoplasma concentrations in various plant hosts as determined by competitive polymerase chain reaction. Phytopathology 90:1145-1152.

8. Bianco, P. A., Frosini, A., Casati, P., and De Bellis, G. 2003. Identification of phytoplasma infecting grapevine by ligase detection reaction and universal array. Page 55 in: Proc. 14th Int. Conf. Viruses of Grapevine, Locorotondo (Bari), Italy.

9. Boudon-Padieu, E. 2003. The situation of grapevine yellows and current research directions: distribution, diversity, vectors, diffusion and control. Pages 47-50 in: Proc. 14th Int. Conf. Viruses of Grapevine, Locorotondo (Bari), Italy.

10. Boudon-Padieu, E., Bejat, A., Clair, D., Larrue, J., Borgo, M., Bertotto, L., and Angelini, E. 2003. Grapevine yellows: comparison of different procedures for DNA extraction and amplification with PCR for routine diagnosis of phytoplasmas in grapevine. Vitis 42:141149.
11. Caudwell, A., and Kuszala, C. 1992. Mise au point d'un test ELISA sur les tissues de vignes atteintes de Flavescence dorée. Res. Microbiol. 143:791-806.

12. Caudwell, A., Kuszala, C., Bachelier, J. C., and Larrue, J. 1970. Transmission de la flavescence dorée de la vigne aux plantes herbacées par l'allongement du temps d'utilisation de la cicadelle Scaphoideus titanus Ball et l'étude de sa survie sur un grand nombre d'éspèces végétales. Ann. Phytopathol. 3:95-105.

13. Clair, D., Larrue, J., Aubert, G., Gillet, J., Cloquemin, G., and Boudon-Padieu, E. 2003. A multiplex nested-PCR assay for sensitive and simultaneous detection and direct identification of phytoplasma in the Elm yellows group and Stolbur group and its use in survey of grapevine yellows in France. Vitis 42:151-157.

14. Cohen J. 1960. A coefficient of agreement for nominal scales. Educ. Psychol. Meas. 20:3746.

15. Constable, F. E., Gibb, K. S., and Symons, R. H. 2003. Seasonal distribution of phytoplasma in Australian grapevines. Plant Pathol. 52:267276.

16. Conti M., D'Agostino G., Casetta A., and Mela, L. 1988. Some characteristics of chrysanthemum yellows disease. Acta Hortic. 234:129-136.

17. Davis, R. E., and Lee, I. M. 1993. Cluster specific polymerase chain reaction amplification of $16 \mathrm{~S}$ rDNA sequences for detection and identification of mycoplasma-like organisms. Phytopathology 83:1008-1011.

18. Demeke, T., and Adams, R. P. 1992. The effects of plant polysaccharides and buffer additives on PCR. Biotechniques 12:332-334.

19. Deng, S., and Hiruki, C. 1991. Amplification of $16 \mathrm{~S}$ rRNA genes from culturable and nonculturable mollicutes. J. Microbiol. Methods 14:53-61.

20. Firrao, G., Gobbi, E., and Locci, R. 1993. Production of oligonucleotide probes for mycoplasma-like organisms using the polymerase chain reaction. Phytopathology 83:602-607.

21. Firrao, G., Palmano, S., Malossini, G., Tomada, I., Carpanelli, A., Dazzan, M., and Frausin, C. 1999. Monitoring grapevine yellows in North-Eastern Italy. J. Plant Pathol. 82:73.

22. Galen, R. S. M., and Gambino, S. R. 1975. Beyond normality: the predictive value and efficiency of medical diagnoses. John Wiley \& Sons, Inc., New York.

23. Galetto, L., Marzachì, C., and Bosco, D. 2005. Universal and group specific real-time PCR diagnosis of Flavescence dorée (16Sr-V), Bois noir $(16 \mathrm{Sr}$-XII) and apple proliferation $(16 \mathrm{Sr}$ X) phytoplasmas from field-collected plant hosts and insect vectors. Ann. Appl. Biol. 147:191-201.

24. Gundersen, D. E., and Lee, I. M. 1996. Ultrasensitive detection of phytoplasmas by nested PCR assays using two universal primer pairs. Phytopathol. Mediterr. 35:114-51.

25. IRPCM Phytoplasma/Spiroplasma Working Team-Phytoplasma Taxonomy Group. 2004 "Candidatus Phytoplasma": a taxon for the wall-less, non-helical prokaryotes that colonize plant phloem and insects. Int. J. Syst. Evol. Microbiol. 54:1243-1255.

26. Kuszala, C. 1996. Influence du milieu d'extraction sur la détection du Bois noir et de la Flavescence dorée de la vigne, par des anticorps poly et monoclonaux diriges contre les phytoplasmas du stolbur et de la Flavescence dorée. Agronomie 16:355-365.

27. Langer, M., and Maixner, M. 2004. Molecular characterization of grapevine yellows associated phytoplasmas of the stolbur-group based on RFLP-analysis of non-ribosomal DNA. Vitis 43:191-200.

28. Lee, I. M., Davis, R. E., and Gundersen Rindal, D. E. 2000. Phytoplasma: Phytopatho- 
genic mollicutes. Annu. Rev. Microbiol. 54:221-255.

29. Lee, I. M., Gundersen, D. E., Hammond, R. D., and Davis, R. E. 1994. Use of mycoplasma like organism (MLOs) group specific oligonucleotide primers for nested-PCR assays to detect mixed-MLO infections in a single host plant. Phytopathology 84:559-566.

30. Marzachì, C., Alma, A., D'Aquilio, M., Minuto, G., and Boccardo, G. 1999. Detection and identification of Phytoplasmas infecting cultivated and wild plants in Liguria (Italian Riviera). J. Plant Pathol. 81:127-136.

31. Morone, C., D'Aquilio, M., Veratti, F., and Marzachì, C. 2004. Diagnosi di flavescenza dorata: sintomi e analisi molecolare. Inf. Fitopatol. 54:20-24.

32. Osman, F., Leutenegger, C., Golino, D., and Rowhani, A. 2007. Real-time RT-PCR (TaqMan) assays for the detection of Grapevine Leafroll associated viruses 1-5 and 9. J. Virol. Methods 141: 22-29.

33. Osman, F., and Rowhani, A. 2006. Application of a spotting sample preparation technique for the detection of pathogens in woody plants by RT-PCR and real-time PCR (TaqMan). J. Virol. Methods 133:130-136.

34. Palmano, S. 2001. A comparison of different phytoplasma DNA extraction methods using competitive PCR. Phytopathol. Mediterr. 40:99-107.

35. Poggi Pollini, C., Giunchedi., L., and Bissani, R. 1997. Immunoenzymatic detection of PCR products for the identification of phytoplasmas in plants. J. Phytopathol. 145: 371-374.

36. Rowhani, A., Biardi, L., Johson, R., Saldarelli, P., Zhang, Y. P., Chin, J., and Green, M. 2000. Simplified sample preparation method and one-tube RT-PCR from grapevine viruses. Page 142 in: Proc. XIII Int. Council for the Study of Viruses and Virus-like Diseases of the Grapevine, Adelaide, Australia.

37. Salomone, A., Mongelli, M., Roggero, P., and Boscia, D. 2004. Reliability of detection of Citrus tristeza virus by an immunochromatographic lateral flow assay in comparison with ELISA. J. Plant Pathol. 86:43-48.

38. Schneider, B., and Seemüller, E. 1994. Presence of two sets of ribosomal genes in phytopathogenic mollicutes. Appl. Environ. Microbiol. 60:3409-3412.

39. Schneider, B., Seemüller, E., Smart, C. D., and Kirkpatrick, B. C. 1995. Phylogenetic classification of plant pathogenic mycoplasma-like organisms or phytoplasmas. Pages 360-380 in: Molecular and Diagnostic Procedures in Mycoplasmology, vol.1. S. Razin and J. G. Tully, eds. Academic Press, San Diego, CA.

40. Skoric, D., Saric, A., Vibio, M., Murari, E., Krajacic, M., and Bertaccini, A. 1998. Molecular identification and seasonal monitoring of phytoplasmas infecting Croatian grapevines. Vitis 37:171-175.

41. Thompson, J. D., Higgins, D. G., and Gibson, T. J. 1994. CLUSTAL W: improving the sensitivity of progressive multiple sequence alignment through sequence weighting, positionspecific gap penalties and weight matrix choice. Nucleic Acids Res. 22:4673-4680. 